\title{
THE MOISTURE REQUIREMENTS AND MANAGEMENT OF IRRIGATED PASTURE
}

By H. G. HOPEWELL, Scientific Officer, Department of Agriculture's Rukuhia Soil Research Station.

The previous paper dealt with the broad fundamentals underlying the moisture requirement of pastures. In making my contribution to this symposium I will attempt to consider the implications of these principles in determining a practical irrigation schedule and to discuss the management of irrigated pastures.

Firstly the irrigation schedule: Mr Rickard has indicated that the-rate-of-water-use by pastures-is - between-0.1-and- 0.2 in - perday and that growth begins to be affected when the amount lost from the soil is of the order of 1 to I\&in., that is, when a deficit of 1 to $I_{2}^{\frac{1}{2}}$ in. is built up,

Similar data have been obtained at the Rukuhia Soil Research Station. The average daily rate of water use in the Waikato is considered to be as in Table 1. For short periods the actual loss can be very much higher, as much as 0.2 in. per day.

Table 1.

\begin{tabular}{lcc}
\hline & $\begin{array}{c}\text { Inches } \\
\text { per day }\end{array}$ & $\begin{array}{c}\text { Days to } \\
\text { use 1in. }\end{array}$ \\
\hline November & 0.12 & 9 \\
December & 0.13 & 8 \\
January & 0.15 & 7 \\
February & 0.13 & 8 \\
March & 0.10 & 10 \\
\hline
\end{tabular}

Furthermore experiments on two Waikato soil types confirm the need to irrigate when 1 to $1 \frac{1}{2}$ in. has been lost. Although we have not carried out any trials on the lighter sandy soils, it is considered that, because these have a smaller reservoir of available water, they are likely to need irrigation at more frequent intervals but with smaller amounts.

Evidence indicates that the irrigation schedule at least on medium loams should be based on irrigating when about I in. of water has been used. The average intervals between irrigations will then depend on the rate of water use and will be of the order shown in Table I.

Now how does the farmer formulate an appropriate irrigation routine? In practice there are three methods he can adopt: 
1. He can apply fixed amount each time, say I in., and vary the interval according to the rate of water use. This is the best approach, since it replaces the water as soon as the loss has reached a point where it begins to affect growth. On the other hand, because it involves irregular intervals it presents more problems in planning farm work and so on. Recommendations for this case are given in Table 2.

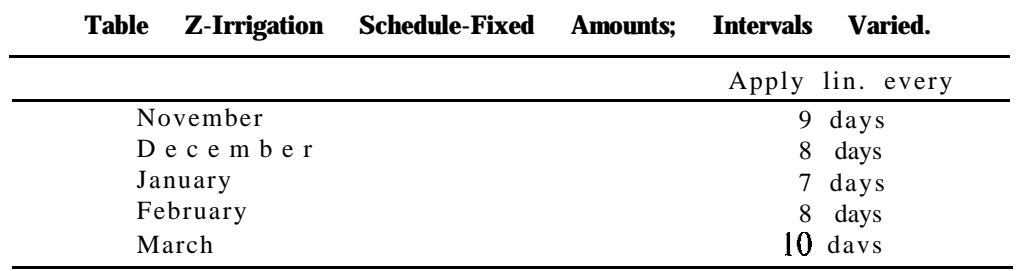

2. A schedule based on fixed intervals is most likely to be acceptable. In this case there are two possibilities:

(a) The amount can also be fixed, or

(b) The amount can be varied according to the rate of use over the period since the previous irrigation. In the first case there will be an obvious waste of water and consequently money, because if the amount applied is adequate for, say, January, it is excessive in other months. In either case if too long an interval is adopted the deficit built up is likely to affect growth. If short intervals are adopted, unnecessary work is entailed. Recommendations are given in Table 3 .

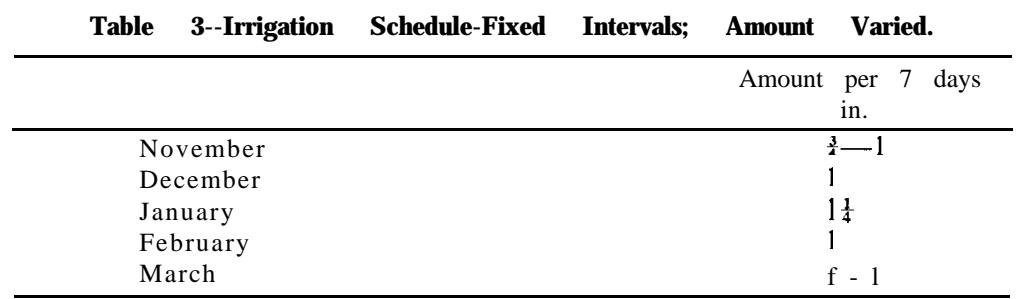

Natural rainfall can be allowed for in two ways: by continuing the irrigation schedule and reducing the amount applied, or by delaying the schedule. A delay of one day for each $0.2 \mathrm{in}$. of rain is recommended. Falls of less than 0.2in. should be disregarded. I would advocate strongly that the irrigator should have his own rain gauge.

It is important to realise that these are the amounts of water required in the soil, not the amount the irrigator thinks or hopes he is putting there. Experienced field officers assert that the two most important causes of poor response to irrigation are in- 
sufficient water being applied and irrigation not being started soon enough in the season; in other words, too little and too late.

The old saying that there is many a slip 'twixt cup and lip can be true here. In some cases the irrigation schedule adopted seems adequate, but in spite of this it is evident that insufficient water is being applied.

There are two important sources of error: failure to allow for evaporation losses and incorrect estimates of water going on.

\section{Evaporation Losses}

Evaporation occurs from the spray in the air and from the droplets on the ground. Losses up to 40 per cent. are quoted in hot, dry climates overseas. Local losses are probably of the order of 10 per cent., but may well be as much as 20 per cent. under some conditions. When irrigation is done at night this loss will bealmost-eliminated-

\section{Estimation of A mount of $W$ ater Being Applied}

This is often based on the assumed pump capacity and arca covered. For various reasons this can give a figure fairly wide of the mark. Some check of actual output should be made either by measuring the flow from some of the sprinklers or by using a series of tins as rain gauges.

The importance of applying sufficient water can bc illustrated by references to a trial conducted at Rukuhia Soil Research Station. Three treatments are involved:

1. Applications of 100 per cent. of that estimated to have been lost, and

2. Application of 75 per cent., and

3. No irrigation.

In the 1956-57 season the soil was thoroughly wet on 4 January. No effective rain fell from 7 January till 8 March.

For 3 weeks production was similar on treatments $\mid$ and 2, but had fallen on non-irrigated plots to about 50 per cent. of that on 1.

During February production fell markedly on the plots receiving insufficient water, actually approximately 55 per cent. There was no measurable production on the non-irrigated ones.

\section{Start of I rrigation}

This is often delayed too long with the result that growth almost ceases and it takes some time to stimulate it again even after the water is applied.

Examination of rainfall records at Hamilton reveals that irrigation is seldom warranted before November. On the other 
hand, only in exceptional seasons can it be delayed till after Christmas.

From October onwards the position should be watched. About 7 or 8 days with no appreciable rain and none forecast will mean that irrigation should start.

Where the initial irrigation has to be delayed through harvesting or other urgent farm operations additional water should be applied the first time round. This should be sufficient to make good the deficit which has accumulated; that is, the soil profile should be thoroughly wetted to a depth of $12 \mathrm{in}$. or more.

Time of I rrigation in R elation to Time of Grazing

Aspects of the irrigation schedule such as rate or rapidity of application and uniformity of distribution will no doubt be referred to by Mr Homersham. I would like, however, to comment on one further point. This concerns the time of applying water relative to the time of grazing.

Dr K. Mitchell of Grasslands Division has focused attention on the fact that high summer temperatures can have an important effect on pasture growth. Of particular importance is the temperature and humidity in and just above the soil surface. When the pasture is eaten off and the cover removed, temperatures will rise and the humidity will drop, conditions that are likely to give a check to growth. Furthermore Jantti in a paper at the International Grassland Congress last year drew attention to the fact that a defoliated plant finds it more difficult to obtain water from the partly dried out soil than does an intact plant. Thus, although we have no direct experimental evidence, it is suggested, on what appear to be sound grounds, that irrigation should follow immediately after grazing. In practice this will be difficult to arrange, but it should be followed when possible.

Pasture for I rrigation

It is obvious that if a pasture is to give a good response to irrigation, it must be capable of high summer production.

The response to irrigation of various pasture species has been the subject of several trials at Rukuhia.

In a field trial under cattle grazing, short-rotation ryegrass, perennial ryegrass, and cocksfoot sown with red and white clover were compared. It was evident from this trial that under Waikato conditions the ryegrasses were incapable of high production even under adequate irrigation. What happened was that the shortrotation practically disappeared in summer, leaving an almost pure clover sward. This, however, flourished under irrigation and the total herbage produced was only slightly less than that from the cocksfoot. Perennial ryegrass persisted better, but became clover dominant. 
On the other hand, cocksfoot not only responded well, but, given proper management, a good grass/clover balance was maintained.

In a plot trial, short-rotation, Italian, and perennial ryegrass, cocksfoot, timothy, phalaris, meadow fescue, and paspalum each sown with white clover were compared. The ryegrasses showed to least advantage.

Paspalum gave high summer yields, but suffered from the disadvantage that it produced practically nothing outside the irrigation period. At this stage there seems to be no case for a special-purpose irrigation pasture; in other words, it is no use growing a pasture that will produce well under irrigation and be a passenger for the rest of the year. This limits its use to those areas where it can be combined successfully with ryegrass and white clover.

Our evidence- suggests that under local co $\bar{n}$ ditions cocksfoot should be a major species in a pasture to be irrigated.

\section{Fertiliser Requirements}

If a good response is to be obtained from irrigation, it is important that lack of plant nutrients should not be a limiting factor.

A certain amount of experimental work has been done and the following general comments are made:

Phosphate: Trials on an area of Hamilton clay loam which had been adequately topdressed showed no response to heavier than normal topdressings of phosphate.

Nitrogen: Spring applications of nitrogenous fertilisers failed to give a response.

In another trial sulphate of ammonia was applied with each irrigation at the rate of $\frac{1}{4} \mathrm{cwt}$. per acre, giving a total for the season of $23 \mathrm{cwt}$. No effect was observed in the first season. This trial is being continued.

Potash: No trials have yet been carried out at the station, but some field officers consider its use may be worth while in certain cases.

The trials quoted refer to conditions where the areas are grazed in such a way that there would be little transference of fertility.

I would, however, like to mention the particular case where ration grazing is practised. In this case the cows will be offered a ration which they will eat in a couple of hours. Under these conditions the animals will tend to go in empty and come out full and there will inevitably be a transfer of fertility; and since the same area is likely to be irrigated year after year, this effect will be cumulative. 
Over nine years the average pasture production from irrigated areas over the period December to March inclusive has been about 60001b. D.M./acre. Assuming that about half this were removed, the following loss of nutrients would occur annually:

Phosphate equivalent of $1 \mathrm{cwt}$. superphosphate.

Potash equivalent of $\mathrm{I} \rightarrow 1 \frac{1}{2} \mathrm{cwt}$. muriate.

Nitrogen equivalent of $4 \mathrm{cwt}$. nitrolime.

In addition small but possibly not unimportant amounts of minor nutrients may be removed.

It is probable that the loss of nitrogen may be made good through the white clover which flourishes under irrigation. The other nutrients must, however, be depleted in due course. The time taken for an effect to appear will depend on the initial fertility.

It is recommended that under these conditions the normal fertiliser dressings be increased by the equivalent of:

$1 \mathrm{cwt}$. superphosphate per acre and

Icwt. muriate of potash per acre.

\section{Management of Irrigated Pastures}

One of the weaknesses of irrigation as at present practised is the inefficient management of the pastures. All too often one sees cows grazing the irrigated paddocks almost continuously. Yet it is an axiom of good pasture management that to grow grass it must be spelled. That this is true of irrigated pastures is shown by a trial at Rukuhia Soil Research Station where spelling for 20-day as opposed to 10-day intervals has increased the yield about 40 per cent.

Another aspect of this trial has shown the importance of maintaining a cover of grass by grazing leniently, especially in the hotter months.

In view of the cost of producing grass under irrigation, every attempt must be made to get maximum yield and utilisation; otherwise there can be little hope that this method of providing summer fodder will be economic.

Two methods of feeding irrigated pasture will be possiblc.

I. Where ample irrigated pasture is available, it will provide the full diet of the cow.

2. More commonly, the area irrigated will not be sufficient for this and the irrigated pasture will be regarded as a milking supplement.

In either case it should be utilised in the same way: fed off in breaks, spelled adequately, and not grazed too hard.

Where it is used to supplement the normal pasture, care should be taken to see that a consistent ration is available. 
The use of harrows to spread the dung is desirable.

\section{Conclusion}

In conclusion I would like to make the point that if irrigation is to pay, the job must be done properly. This means that adequate amounts of water must be applied at proper intervals to a suitable pasture which must then be managed and utilised efficiently. This in turn means having satisfactory equipment, the required labour, and the necessary enthusiasm.

\section{DISCUSSION}

Q. What is the cause of the slump in pasture production in February in the trial you referred to?

A. It was, I believe, largely a matter of the pasture species involved. The sward in the trial consisted of perennial ryegrass and white clover, and this type of pasture characteristically shows a slump in production in the hotter months even under irrigation.

The application of rather more water than was used may have been an advantage,

Dr Annett stated that his experience with spray irrigation confirmed the findings presented by $\mathrm{Mr}$ Hopewell. Dr Annett said he had found H.1. inferior to cocksfoot and prairie grass, both of which did well under irrigation. He further stressed the need to spell irrigated pastures and also reported that he had no success from the use of sulphate of ammonia under irrigation.

Dr Mitchell reported that, at Grasslands Division, Palmerston North, long pasture had conserved I tin. of moisture within several weeks in summer. In spring the reverse occurred, more moisture being used by the long pasture. Long pasture was wilting while short pasture alongside was at field capacity. Has $\mathrm{Mr}$ Hop-well found similar effects?

A. Although we have no precise data, our observations are in line with Dr Mitchell's findings.

Q. What is the relative value of red and white clover over the irrigation period?

A. There is very little data available from our trials on this aspect. In one trial perennial ryegrass, H.l., and cocksfoot were each sown with red and white clover. In no case did the red clover survive for more than 2 or 3 seasons.

Q. We have also found that H.l. dies out under irrigation at Grasslands. Tall white clover shaded H.1. and killed it. Losses were less under close grazing. Could the grazing management be a factor in the disappearance of H.l. observed in your trial?

A. Each species in the trial, perennial rye, H.l., and cocksfoot, were sown with red and white clover in separate blocks and each area was grazed separately and managed in a manner considered to be in the best interests of the species concerned. Although our grazing of the H.I. may have been a little too lenient, I do not think it was an important factor in the disappearance of the H. 1.

Q. Was there greater water conservation under the lenient grazing which also gave better returns?

A. Yes. there is evidence to show that water losses are less under long than short pastures during the irrigation period. 